\title{
Knowledge of nursing professionals of a surgical center regarding malignant hyperthermia
}

\author{
Conhecimento dos profissionais de enfermagem de \\ centro cirúrgico sobre hipertermia maligna \\ Conocimiento de los profesionales de enfermería de \\ un centro quirúrgico sobre hipertermia maligna
}

D0l: $\quad$ http://dx.doi.org/10.1590/1983-

1447.2014.03.44643

\footnotetext{
${ }^{a}$ M.Sc. in Adult Health Nursing from the School of Nursing, University of São Paulo. Clinical Nurse in the operating room of the Sírio-Libanês [SyrianLebanese] Hospital, Sao Paulo (SP), Brazil.

${ }^{b}$ M.Sc. in Adult Health Nursing from the School of Nursing, University of São Paulo. Coordinating Nurse in the operating room of the Sírio-Libanês [SyrianLebanese] Hospital, Sao Paulo (SP), Brazil.
}

\section{ABSTRACT}

The objective of this study was to assess the knowledge of the nursing professionals in a surgical center about malignant hyperthermia. This is a descriptive exploratory study on malignant hyperthermia conducted with mid- and high-level nursing professionals in the surgical center of an institution located in the city of São Paulo, where the research was conducted between August and September 2013. Analysis of the data was descriptive and the average of the correct answers was compared using Student's t-test. Among the 96 participants, the two items in which at least $70 \%$ of the team showed knowledge were: the definition of malignant hyperthermia and the professionals involved in the health care provided. With respect to all test items, $70 \%$ of nurses answered $50 \%$ correctly. The same percentage of mid-level professionals answered only $20 \%$ correctly. There was no statistically significant difference between the professional categories. This study revealed insufficient knowledge on the part of the nursing team about malignant hyperthermia. Descriptors: Malignant hyperthermia. Perioperative nursing. Evidence-based nursing.

\section{RESUMO}

Este estudo tem por objetivo avaliar o conhecimento dos profissionais de enfermagem de um centro cirúrgico sobre a hipertermia maligna. Trata-se de um estudo descritivo exploratório com profissionais de enfermagem de nível médio e superior do centro cirúrgico da instituição sede da pesquisa, situada na cidade de São Paulo, sobre a hipertermia maligna entre agosto-setembro de 2013. A análise de dados foi descritiva e a média de acertos foi comparada por teste estatístico t Student. Dos 96 participantes, os dois itens nos quais pelo menos 70\% da equipe demonstra ter conhecimento são a definição de hipertermia maligna (HM) e os profissionais envolvidos no atendimento. Em relação a todos os itens do teste, setenta por cento dos enfermeiros obtiveram acertos em $50 \%$ dos itens do teste, a mesma porcentagem de profissionais de nível médio acertou apenas $20 \%$, não houve diferença estatística significante $(p=0,09)$ entre as categorias profissionais. Este estudo evidenciou insuficiente conhecimento da equipe de enfermagem sobre a hipertermia maligna.

Descritores: Hipertermia maligna. Enfermagem perioperatória. Enfermagem baseada em evidências.

\section{RESUMEN}

Este estudio tuvo por objetivo evaluar el conocimiento de los profesionales de enfermería de un centro quirúrgico sobre la hipertermia maligna. Este es un estudio descriptivo exploratorio sobre la hipertermia maligna realizado con profesionales de enfermería de nivel medio y superior del centro quirúrgico de una institución ubicada en la ciudad de São Paulo donde se realizó la investigación entre agosto y septiembre de 2013. El análisis de los datos fue descriptivo y el promedio de respuestas correctas fue comparado usando la prueba t de Student. Entre los 96 participantes, los dos ítems en los que al menos el $70 \%$ del equipo demostró conocimiento fueron la definición de hipertermia maligna y los profesionales involucrados en la atención al paciente. Con respecto a todos los ítems de la prueba, el 70\% de los enfermeros respondió correctamente el 50\%. El mismo porcentaje de profesionales de nivel medio solo respondió correctamente el 20\%. No hubo ninguna diferencia estadística significativa entre las categorías profesionales. Este estudio mostró insuficiente conocimiento del equipo de enfermería sobre la hipertermia maligna.

Descriptores: Hipertermia maligna. Enfermería perioperatoria. Enfermería basada en la evidencia. 


\section{口INTRODUCTION}

Malignant hyperthermia $(\mathrm{MH})$ is a potentially fatal musculoskeletal disorder; it occurs in genetically predisposed patients and those immediately exposed to halogenated agents and succinylcholine, triggering an increase in intracellular free calcium concentration in the cytoplasm of skeletal muscle cells. This is clinically translated as hypermetabolism and rhabdomyolysis, which, untreated, progress to death, thereby warranting the adjective malignant. ${ }^{(1-2)}$

The occurrence of this syndrome during surgery is an emergency situation and it requires precise treatment with immediate assistance. The paucity of literature on the subject, either nationally or internationally, has raised questions about the level of knowledge of our nursing staff on the subject, and thus we propose to answer the research question: Do you think we are prepared to attend a patient with a crisis of $\mathrm{MH}$ ?

The incidence of $\mathrm{MH}$ varies between countries and states, presumably because of genetic differences in the population. A Japanese study conducted in the period 2006-2008 shows a prevalence of 13.7 cases per million. ${ }^{(3)}$ In New York, a study describes 73 cases diagnosed from 2001-2005. ${ }^{(4)}$ In Brazil, there are no current data on the incidence; however, it is estimated that general anesthesia is performed approximately five million times annually, and therefore this number is consistent with the annual incidence of 500 to 1,000 cases of MH in São Paulo alone. ${ }^{(5)}$

Clinical signs that may indicate the onset of $\mathrm{MH}$ are: unexplained tachyarrhythmias, which may occur in $96 \%$ of cases; tachypnea in $85 \%$ of patients; and acidosis in $80 \%$ of patients in response to increased gluconeogenesis. An event will also produce abnormal amounts of lactic acid, carbon dioxide $\left(\mathrm{CO}_{2}\right)$, and heat, as well as sustained contraction of muscle groups, which leads to greater use of available adenosine triphosphate (ATP) and oxygen. Muscle stiffness is generally an early sign of $\mathrm{MH}$ and is present in approximately $80 \%$ of patients, particularly when administered muscle relaxants. The masseter muscle is one of the muscle groups most frequently involved. ${ }^{(6-7)}$

The nursing staff should be aware that there is a direct correlation between the severity of an episode of $\mathrm{MH}$ and the availability of treatment. Thus, any delay in the early recognition and prompt treatment of a patient with $\mathrm{MH}$ may result in sudden death by cardiac arrest, brain damage, multiple organ failure, or disseminated intravascular coagulation (DIC). ${ }^{(2,6,8)}$

Considering the importance for patient safety and the participation and contribution of nurses who work in the surgical center during care for patients in crisis, the aim of this study is to assess the knowledge of malignant hyperthermia among the nursing professionals in a surgical center.

\section{$\square$ METHOD}

This is a quantitative study on $\mathrm{MH}$ with a descriptive design in which a systematic search was conducted on the knowledge of the nurses and nursing technicians working in the research institution's headquarters, located in the city of São Paulo. The project was approved by the Research Ethics Committee of the institution where it was conducted (Process No. 354.937/2013). All participants signed an Informed Consent Form (ICF) before the start of data collection, respecting the ethical principles of research with human beings and research ethics with humans, based on Resolution 466/12 of the National Health Council.

The inclusion criterion applied was nursing professionals with expertise in the surgical center of the research institution's headquarters. The exclusion criteria applied were for professionals with assistant training in nursing, and professionals who were on vacation or sick leave during the research's period of data collection.

The group of nursing professionals who worked directly with care in the surgical center in the research institution was composed of 23 nurses and 110 nursing technicians. Based on a sample size calculation with an alpha error of $0.05 \%$ for 127 professionals, 96 professionals were included in the sample of this research.

The surgical center of the hospital researched consists of 19 operating rooms and 20 beds for post-anesthesia recovery. It is a large, private, philanthropic hospital based in the municipality of São Paulo. On average, 1,500 surgeries are performed per month.

Data collection was conducted in the months of August and September 2013, using an instrument constructed by the researcher, based on the practices recommended by the Association PeriOperative Registered Nursing (AORN). This nonprofit association represents the interests of more than 160,000 perioperative nurses, providing nursing education, standards, and practices, and a monthly publication on perioperative nursing. Following the study, it was validated by three specialist nurses in the surgical center by means of group discussion and subjected to Cronbach's alpha reliability analysis. The instrument developed comprises a theoretical evaluation with 10 questions, and five possible answers for each question; only one of these alternatives was correct.

The completion of the knowledge test aimed to measure the participants' level of knowledge on the recommendations for $\mathrm{MH}$. This test comprises knowledge about 
the definition of the pathology, diagnosis, and treatment, side effects of medication, existence of a protocol to attend the crisis, resources for recording the occurrence, and professionals who work during the MH crisis.

One point was assigned for each correct answer. The total score on the knowledge test corresponded to the sum of all the correct answers. To consider knowledge on the subject, it was decided to present the test results in score bands at or above $70 \%$.

The instrument was distributed to professionals who agreed to participate and who had signed the Informed Consent Form. They answered individually, during working hours, and returned the instrument to the researcher immediately upon completion; despite identification used in the instrument, the results were kept anonymous.

The data collected were entered into a Microsoft Excel for Mac ${ }^{\oplus 2011}$ spreadsheet using the technique of double entry for analysis using the Statistical Package for Social Science, version 20.0 (SPSS). The analysis considered the scores of the two groups of professionals, i.e., the nursing technicians and the nurses, and not isolated scores for each subject. The variables related to sociodemographic characteristics (age, gender, and length of professional training) and knowledge test answers were summarized and presented descriptively using frequency distribution, absolute values, means, and standard deviations. For evaluation of the knowledge test, Student's t-test was applied to two independent samples. The level of significance was $p<0.05$.

\section{RESULTS}

A total of 96 members of the nursing staff from the surgical center participated in the survey, which corresponds to $67.13 \%$ of the active staff in the unit, 89 nursing technicians and seven nurses. The data obtained resulted in a mean age of $36 \pm 8.15$ years; for the nursing technicians the average age is $36.4 \pm 8.4$ years and for the nurses the average age is $31 \pm 4$ years. As regards gender, the majority observed in both groups were female. Nursing technicians had more professional training, with a mean of $10.7 \pm 3$ years, with nurses having a mean of $7.1 \pm 7.3$ years. The distribution of participants according to socio-demographic characteristics is presented in Table 1.

Considering the overall results of the test, the nursing technicians obtained a mean of $5.82 \pm 1.78$ points reached and the nurses $6.29 \pm 0.95$. The Student t-test showed no

Table 1 - Socio-demographic characteristics of the participants according to professional category. São Paulo, SP, 2013.

\begin{tabular}{|c|c|c|c|c|c|c|}
\hline \multirow{2}{*}{ Variables } & \multicolumn{2}{|c|}{ Nursing technicians $(n=89)$} & \multicolumn{2}{|c|}{ Nurses $(n=07)$} & \multicolumn{2}{|c|}{ Total $(n=96)$} \\
\hline & $\mathbf{N}$ & $\%$ & $\mathbf{N}$ & $\%$ & $\mathbf{N}$ & $\%$ \\
\hline \multicolumn{7}{|l|}{ Age (years) } \\
\hline $20-30$ & 21 & 23.6 & 5 & 71.4 & 26 & 27.1 \\
\hline $31-40$ & 43 & 48.3 & 2 & 28.6 & 45 & 46.9 \\
\hline $41-50$ & 20 & 22.5 & - & - & 20 & 20.8 \\
\hline $51-60$ & 5 & 5.6 & - & - & 5 & 5.2 \\
\hline Total & 89 & 100 & 7 & 100 & 96 & 100 \\
\hline \multicolumn{7}{|l|}{ Sex } \\
\hline Female & 59 & 66.3 & 5 & 71.4 & 64 & 69.4 \\
\hline Male & 30 & 33.7 & 2 & 28.6 & 32 & 34.7 \\
\hline Total & 89 & 100 & 7 & 100 & 96 & 100 \\
\hline \multicolumn{7}{|c|}{ Length of professional training (years) } \\
\hline$<5$ & 23 & 25.8 & 3 & 42.9 & 26 & 27.1 \\
\hline $6-10$ & 32 & 36.0 & 3 & 42.9 & 35 & 36.5 \\
\hline $11-20$ & 27 & 30.3 & 1 & 14.3 & 28 & 29.2 \\
\hline$>20$ & 7 & 7.9 & - & - & 7 & 7.3 \\
\hline Total & 89 & 100 & 7 & 100 & 96 & 100 \\
\hline
\end{tabular}


Table 2 - Level of knowledge according to the number of correct answers per professional category. São Paulo, SP, 2013.

\begin{tabular}{|c|c|c|c|c|c|c|}
\hline \multirow[t]{2}{*}{ Knowledge test } & \multicolumn{2}{|c|}{$\begin{array}{c}\text { Nursing } \\
\text { technicians }(\mathrm{n}=\mathbf{8 9})\end{array}$} & \multicolumn{2}{|c|}{ Nurses $(\mathrm{n}=07)$} & \multicolumn{2}{|c|}{ Total $(n=96)$} \\
\hline & $\mathbf{N}$ & $\%$ & $\mathbf{N}$ & $\%$ & $\mathbf{N}$ & $\%$ \\
\hline Definition of problem & 77 & 86.5 & 6 & 85.7 & 83 & 86.5 \\
\hline Triggering agents of the crisis & 56 & 62.9 & 6 & 85.7 & 62 & 64.6 \\
\hline Initial clinical manifestations & 28 & 31.5 & 1 & 14.3 & 29 & 30.2 \\
\hline Treatment of $\mathrm{MH}$ & 42 & 47.2 & 3 & 42.9 & 45 & 46.9 \\
\hline Main side effects & 51 & 57.3 & 5 & 71.4 & 56 & 58.3 \\
\hline $\begin{array}{l}\text { Availability of medication for treatment at the } \\
\text { institution }\end{array}$ & 57 & 64.0 & 5 & 71.4 & 62 & 64.6 \\
\hline Availability of care protocol for crisis & 26 & 29.2 & - & - & 26 & 27.1 \\
\hline $\begin{array}{l}\text { Prevention of incidence for patients with prior } \\
\text { diagnosis and high risk }\end{array}$ & 60 & 67.4 & 4 & 57.1 & 64 & 66.7 \\
\hline Notification to surveillance centers & 54 & 60.7 & 4 & 57.1 & 58 & 60.4 \\
\hline Professionals involved in the care of the crisis & 70 & 78.7 & 7 & 100 & 77 & 80.2 \\
\hline Mean of overall correct answers & \multicolumn{2}{|c|}{5.82} & & & \multicolumn{2}{|c|}{5.90} \\
\hline
\end{tabular}

Source: data from the research questionnaire.

significant difference $(p=0.09)$. Using Cronbach's alpha, the reliability was 0.33 .

The results obtained by the professionals in the knowledge test, per item, are shown in Table 2.

\section{DISCUSSION}

This is an unprecedented study aimed at responding to our concerns about the knowledge of our nursing team regarding $\mathrm{MH}$. A patient with a crisis of $\mathrm{MH}$ requires diagnosis, treatment, and immediate assistance to enable the reversal of the clinical situation and avoid sudden death.

Cronbach's alpha values of 0.33 refer to low levels but do not affect the outcome of the study, because a sample of people with similar backgrounds and experience can result in an unreliable questionnaire. In an evaluation instrument, when the sample population indicates a single true item value of 5 (assuming a range of absolute values ranging from 1 to 5), there is no variance of the item and, hence, the calculated reliability value will be zero.

The results of this study showed an insufficient knowledge of $\mathrm{MH}$ on the part of the nursing staff. The two items in which at least $70 \%$ of the staff demonstrated some knowledge are in the definition of $\mathrm{MH}$ and the professionals involved in the care. In relation to all test items, $70 \%$ of the nurses got $50 \%$ of the test items right; the same percentage of mid-level professionals got just 20\% right.
A North American study of nursing students raised the issue of the lack of knowledge about treatment and management of $\mathrm{MH}$ among undergraduates; however, the study did not categorize the data about this knowledge.(9)

In a study on the knowledge of Brazilian anesthesiologists faced with $\mathrm{MH}$ with 10 respondents, the researchers found $80 \%$ of correct answers on the diagnosis and $70 \%$ on the treatment. On the other hand, only $20 \%$ of these respondents knew the side effects of dantrolene and 40\% of the responses on the pharmacology of dantrolene were incorrect. ${ }^{(10)}$

In this study, the nurses got at least $80 \%$ of the answers correct on definition, triggering agents, and professionals involved. In the category of diagnosis and treatment, however, the knowledge of these professionals was only $14.3 \%$ and $42.9 \%$ respectively. The nursing technicians had better rates in these categories, at 31.5\% and $47.2 \%$. However, population samples are unequal, and did not allow a furthering of knowledge in the comparison between categories, which was probably related to the educational focus of the professional. Generally, physicians further their knowledge in diagnosis and treatment, and nursing in care.

The absence of or minimal knowledge of $\mathrm{MH}$ may result in failures in the handling of a crisis or the treatment implemented. No studies on the nurses' knowledge of $\mathrm{MH}$ were found in either the national or international literature, so we were unable to do comparisons with our findings. 
In Brazil, a telephone support service for crises in $\mathrm{MH}$ is available from the Federal University of São Paulo (UNIFESP). A prospective study of this service conducted in 2009 resulted in 22 calls; 15 of these were requests for general information about $\mathrm{MH}$. The service concluded that the number of calls is still low and it is necessary to increase the knowledge about MH in Brazil. ${ }^{(5)}$

The results of this study showing that health professionals had little knowledge of the subject of $\mathrm{MH}$ are in agreement with those presented in other studies ${ }^{(5,9,-10)}, \mathrm{em}$ phasizing the need for training and expanding the knowledge of health professionals to enable them to recognize patients who may present a crisis of $\mathrm{MH}$ during the perioperative period.

The SS-20 Resolution of February 22, 2006 from the State of São Paulo defines MH as a disease of immediate compulsory notification, requiring the attending nurse to complete a File for Compulsory Notification of Adverse Events and forward it to the Pharmacovigilance Center of their state. ${ }^{(11)}$ Regarding the reporting of cases of hyperthermia, only $57.1 \%$ of nurses were aware of their responsibility to notify the monitoring centers, which contributes to the underreporting of existing cases.

Since 2007, with well-trained staff, early diagnosis, and quickly instigated treatment, the mortality rate from $\mathrm{MH}$ is around 5\%. Data from 1970 refer to a mortality rate of 80\%. (7) It is recommended that all hospitals have care protocols for this event. ${ }^{(12)}$ Nevertheless, the rate of correct answers on the existence of a care protocol was only $27.1 \%$ from both groups of professionals studied.

Studies on the training and qualification of nursing professionals are described in the international literature. $(7,9,13,14)$ Professional training is directly linked to giving the patient the best chance of success in recovering from the crisis by means of a coordinated multidisciplinary team such as a rapid response team (RRT).(7) The creation of rapid response teams within healthcare institutions has increased in parallel with the increased interest in improving the quality of care. ${ }^{(15)}$

A rapid response team in the operating room acts as a multidisciplinary team aimed at attending the emergency situation. Triggered by a beeper from an operating room professional, a nurse, an anesthesiologist, professionals from the satellite pharmacy, the blood bank, and the coordinators in the surgical center are informed of the emergency situation. It is up to the nurse and the anesthesiologist to help the team in the operating room to deal with a crisis situation.

The AORN recommends that the nursing staff and other professionals in the operating room who may be involved in responding to an $\mathrm{MH}$ crisis receive training and perform activities of validation and competence, applicable to their duties, on the necessary actions to effectively manage an event of the disease. ${ }^{(8)}$ The American Association of Nurse Anesthetists (AANA) also recommends that certified anesthetist nurses maintain their competence through continuing education in the treatment of HM. ${ }^{(16)}$

The competence of nurses in surgical centers still presents many challenges. Since 2000, actions have been focused on patient safety; thus, safety protocols and procedures were put into practice in the surgery center and the nurses' skills have increased. ${ }^{(17)}$

Despite the reduction in the mortality rate in cases of $\mathrm{MH}$, the limited knowledge of the nursing staff on the subject can affect the quality of care of the surgical patient facing an $\mathrm{MH}$ crisis. Training of these professionals on the subject is recommended, as well as training in the care protocol.

\section{- CONCLUSION}

The results of this research demonstrate insufficient knowledge of nurses on the topic of MH. There is a need for training and education on the care of $\mathrm{MH}$ for nurses, due to the low rate of correct answers in the test. Although it is not possible to compare the results with other studies in the nursing field, the low rate of assertiveness on the clinical manifestations may prevent recognition of a crisis in $\mathrm{MH}$ by professionals in this category.

As a limitation of this study, we can cite the presentation of results from a local population that cannot be generalized. The scarcity of research conducted not only in Brazil but globally impedes a comparison of the results of this study with a similar population. This fact complicates the discussion and makes it difficult to draw a conclusion about the overall level of knowledge of nurses in Brazil on the subject of $\mathrm{MH}$.

Among the implications for professional practice, determining the level of knowledge of the nursing staff identifies the areas that need improvement and proposes interventions that result in better care practices. It would be interesting for universities and technical courses to include learning about crisis situations of $\mathrm{MH}$ in their curricula and how to conduct a case in order to better train professionals and prepare them to further their knowledge and develop new research.

We recommend conducting further research based on the knowledge of nursing professionals and educational intervention strategies to improve these levels. Updating nursing professionals should be standard practice in healthcare institutions, as well as in educational and research institutions. 


\section{REFERENCES}

1. Correia $A C$, Silva PC, Silva BA. Malignant hyperthermia: clinical and molecular aspects. Rev Bras Anestesiol. 2012;62(6):820-37.

2. Poore SO, Sillah NM, Mahajan AY, Gutowski KA. Patient safety in the operating room: II. intraoperative and postoperative. Plast Reconstr Surg. 2012;130(5):1048-58.

3. Sumitani M, Uchida K, Yasunaga H, Horiguchi H, Kusakabe Y, Matsuda S, et al. Prevalence of malignant hyperthermia and relationship with anesthetics in Japan: data from the diagnosis procedure combination database. Anesthesiology. 2011;114(1):84-90.

4. Brady JE, Sun LS, Rosenberg H, Li G. Prevalence of malignant hyperthermia due to anesthesia in New York State, 2001-2005. Anesth Analg. 2009;109(4):1162-6.

5. Silva HCA, Almeida CS, Brandao JCM, Silva CAN, Lorenzo MEP, Ferreira CBND, et al. Malignant hyperthermia in Brazil: analysis of hotline activity in 2009. Rev Bras Anestesiol. 2013;63(1):13-9.

6. Escobar DJ. Hipertermia maligna. Rev Med Clin Condes. 2011;22(3):310-5.

7. Dirksen SJH, Van Wicklin SA, Mashman DL, Neiderer P, Merritt DR. Developing effective drills in preparation for a malignant hyperthermia crisis. AORN J. 2013;97(3):329-53.

8. Association of PeriOperative Registered Nurses. Malignant hyperthermia guideline. In: Association of PeriOperative Registered Nurses, editor. Perioperative standards and recommended practices. Denver, CO: A0RN; 2012. p. 621-41.
9. Cain CL, Riess ML, Gettrust L, Novalija J. Malignant hyperthermia crisis: optimizing patient outcomes through simulation and interdisciplinary collaboration. AORN J. 2014;99(2):301-8; quiz 9-11.

10. Macedo M, Buss M. Analysis of the level of information about malignant hyperthermia among anesthesiologists of a public hospital of the Distrito Federal. Cenarium Pharmacêutico. 2011;4(4):1-20.

11. Secretaria de Saúde do Estado de São Paulo. Resolução SS No 20, de 22 de fevereiro de 2006: atualiza a lista de doenças de notificação compulsória no estado de São Paulo. Diário Oficial do Estado de São Paulo (SP) 2006 fev 23. Disponivel em: ftp://ftp.cve.saude.sp.gov.br/doc_tec/nive/dncsp_220206.pdf

12. Sousa CS, Diniz TRZ, Cunha ALSM. Malignant hyperthermia: proposing a care protocol for surgical centers. J Nurs UFPE online. 2013;7(11):6714-8.

13. Mullen L, Byrd D. Using simulation training to improve perioperative patient safety. AORN J. 2013;97(4):419-27.

14. Arriaga AF, Bader AM, Wong JM, Lipsitz SR, Berry WR, Ziewacz JE, et al. Simulation-based trial of surgical-crisis checklists. N Engl J Med. 2013;368(3):246-53.

15. Veiga VC, Carvalho JC, Amaya LEC, Gentile JKA, Rojas SSO. Performance of the rapid response team in the educational process for cardiopulmonary arrest care. Rev Soc Bras Clín Méd. 2013;11(3):258-62.

16. American Association of Nurse Anesthetists. Position statement number 2.5: malignant hyperthermia crisis preparedness and treatment [Internet]. Park Ridge (IL); c2009 [cited 2013 Nov 30]. Disponível em: http://www.asdahq.org/ LinkClick.aspx?fileticket=1zt9j64Dq1M\%3D\&tabid=90

17. Sousa CS, Gonçalves MC, Lima AM, Turrini RNT. Advances in the role of surgical center nurses. J Nurs UFPE on line. 2013;7(nesp):915-23.
Author's address:

Cristina Silva Sousa

Rua Professora Carolina Ribeiro, 20, ap. 54, Vila Mariana

041160-020, São Paulo, SP

E-mail: crissousa@usp.br
Received: 16.01.2014

Approved: 05.06.2014 